\title{
Daily Consumption of Fruits and Vegetables Has Different Correlations With Haemoglobin Levels in Young Women at Karanganyar Regency
}

\author{
$1^{\text {st }}$ Liyana Ilmiyati \\ Postgraduate Student of Nutrition \\ Sciences \\ Universitas Sebelas Maret \\ Surakarta, Indonesia \\ liyanailmiyati@student.uns.ac.id
}

\author{
$* 2^{\text {nd }}$ Dono Indarto \\ Postgraduate Program of Nutrition \\ Sciences, Department of Physiology, \\ Biomedical Laboratory, Faculty of \\ Medicine \\ Universitas Sebelas Maret \\ Surakarta, Indonesia \\ dono@staff.uns.ac.id
}

\author{
$3^{\text {rd }}$ Brian Wasita \\ Postgraduate Program of Nutrition \\ Sciences, Department of Anatomic \\ Pathology, Faculty of Medicine \\ Universitas Sebelas Maret \\ Surakarta, Indonesia \\ brianwasita@yahoo.com
}

\begin{abstract}
Indonesia still encounters a nutritional problem since the morbidity rate of anemia in young women has increased in the last few years. Iron deficiency is the most common cause of anemia in susceptible age groups especially in young women. Based on the results of Basic Health Research in Indonesia, low daily intake of fruits and vegetables commonly occurs in Indonesian people. This study therefore aimed to investigate the correlation of fruit and vegetable consumptions with hemoglobin $(\mathrm{Hb})$ levels in young women. A cross sectional study was performed to 117 young women who studied at senior and vocational high schools in Karanganyar Regency. They were selected by using a stratified random sampling. Data of fruit and vegetable consumptions were collected through a Semi Quantitative-Food Frequency Questionnaire (SQ-FFQ) while $\mathrm{Hb}$ levels were measured by using a hematology analyzer. Data of other factors that influenced $\mathrm{Hb}$ levels were obtained by using questionnaires and anthropometric measurement. Spearman and multiple linear regression tests were used to analyze correlation of fruit and vegetable consumptions and confounding factors with $\mathrm{Hb}$ levels. The $p$-value of $<0.05$ was considered as a statistical significance. Anemia was found in $\mathbf{1 7 . 1 \%}$ young women. Most young women had inadequate fruit consumption whereas $52.1 \%$ had adequate vegetable consumption. Fruit consumption $(b=0.002 ; p=0.740)$ did not correlate with $\mathrm{Hb}$ levels while a positive correlation with $\mathrm{Hb}$ level was observed in vegetable consumption $(b=0.006 ; p<0.001)$. In conclusion, daily consumption of fruits and vegetables has different correlations with $\mathrm{Hb}$ levels in young women.
\end{abstract}

Keywords - Fruit and vegetable consumption, Hemoglobin level, Anemia, Young women

\section{INTRODUCTION}

Many countries in the world have come across anemia for long time periods, in which the prevalence of anemia tended to increase in the last five years [1] In Indonesia for instance, the prevalence of anemia increased from $37.1 \%$ in 2013 to $48.9 \%$ in 2018 and is likely to increase in 2023 . In addition, $84.6 \%$ of anemic cases are found in the $15-24$ year age group including young women [2]. Beside the morbidity rate, anemia in young women also has negative impacts on physical health such as weakness, fatigue, less concentration, and reduced physical activity, causing decreases of life quality and work productivity $[3,4]$.

There are many factors that contribute to anemia, but the most common is due to iron deficiency. Low daily intake of fruits and vegetables is thought to be an important factor which may increase iron deficiency in Indonesia. According to the data of the Basic Health Research in Indonesia (2018), most Indonesian people (95.5\%) had low consumption of fruits and vegetables [2]. However, it is surprising because fruits and vegetables are easily grown and found in all areas in Indonesia [5].

Beside iron and carotenoids, fruits and vegetables are rich in vitamin $\mathrm{C}$. The presence of vitamin $\mathrm{C}$ helps absorb ferric iron from fruits and vegetables by removing the interaction with tannin, phytate, and oxalate [6,7]. Some studies have shown that adequate consumption of fruits and vegetables has contradictory effects on iron bioavailability. In this sense, one side said that there was a positive correlation of daily consumption of fruits and vegetables with serum iron level, but the other side said no correlation [7-9] Therefore, this study aimed to assess the correlation of fruit and vegetable consumption with $\mathrm{Hb}$ levels in young women.

\section{MATERIAL AND METHOD}

This cross-sectional research study was performed at Karanganyar Regency from February to March 2020. Population of this study was young women who studied at high and vocational schools in Colomadu, Jumapolo, and Matesih districts, based on their highest prevalence of anemia in the Karanganyar Regency in 2018. Young women were selected using a stratified random sampling method with the criteria as follows: they were aged 15-18 years old and lived in those districts at least 6 months. The selected young women were excluded from this study when they had menstruation and blood disorders such as thalassemia, worm infection, and malaria. After research participants agreed to participate to this study, they then signed the informed consent. The protocol of this study was also approved by 
The Health Research Ethic Committee of Dr. Moewardi General Hospital, Surakarta (No. 102 / I / HREC / 2020).

According to the Indonesian recommended dietary allowance, adolescents (13-18 year old) should daily consumed fruits and vegetables at least $400 \mathrm{~g} /$ person / day that consists of $150 \mathrm{~g}$ fruits and $250 \mathrm{~g}$ vegetables. If they consumed less than $400 \mathrm{~g} / \mathrm{day}$, it would be classified "less" and vice versa [10]. Data of those intakes were obtained using the SQ-FFQ. Blood samples were taken from the venous lower arms of research participants, and $\mathrm{Hb}$ levels were measured using a hematology analyzer at Health Laboratories in Surakarta City, Jumapolo, or Matesih Community Health Centers. Adolescent Hb levels were $\geq 12$ $\mathrm{g} / \mathrm{dL}$ were categorized as "non-anemic" [11]. Confounding factors in this study such as physical activity, menstrual length, and parent income were collected using the international physical activity and open questionnaires, and body mass index (BMI) for age respectively. The physical activity of research participants was classified into low $(<600$ metabolic equivalent of tasks or METs), medium (600-2999 METs), and high ( $\geq 3000$ METs) categories [12]. Meanwhile, menstrual length was categorized into abnormal (>7 days/ cycle) and normal $(\leq 7$ days/cycle) and classification of parent income was based on minimum regional wage (MRW) in Karanganyar Regency (1.989 million IDR)[13]. The BMI/age was then determined using the $\mathrm{Z}$ score method and was classified into thin (- 3 SD to <$2 \mathrm{SD})$, normal $(-2 \mathrm{SD}$ to $+1 \mathrm{SD})$, overweight $(+1 \mathrm{SD}$ to +2 SD), and obese (>+2 SD)[14].

Collected data in this study were analyzed using the Statistical Product and Service Solutions (SPSS) program, Version 21. Numeric and categorical data were presented as mean \pm standard deviation (SD), and frequency and percentage respectively. Data normality was then verified using the Kolmogorov-Smirnov test, and the correlations of fruit and vegetable consumption and the confounding factors with $\mathrm{Hb}$ levels were assessed using the Rank Spearman test. Finally, regression coefficients of those variables against $\mathrm{Hb}$ levels were analyzed using the multiple linear regression test, and the significant correlation was set up at the p-value < 0.05 .

\section{RESULT}

General characteristics and daily consumption of fruits and vegetables in young women who took part in this study were indicated in Table 1. In general, young women had normal characteristics except fruit consumption and parent income. The average age of young women was $15.8 \pm 0.73$ years old, and $17.1 \%$ among them had anemia. Inadequate consumption of fruits was observed in $86.3 \%$ young women but $52.1 \%$ young women daily consumed adequate vegetables. Furthermore, more than half of parent's young women had low monthly income.

TABLE I. GENERAL CHARACTERISTICS AND DAILY CONSUMPTION OF FRUITS AND VEGETABLES IN YOUNG WOMEN PARTICIPATING IN THIS STUDY

\begin{tabular}{llc}
\hline \multicolumn{1}{c}{ Variable } & \multicolumn{1}{c}{ Mean \pm SD } & $\begin{array}{c}\text { Frequenc } \\
\mathbf{y}(\%)\end{array}$ \\
\hline Age (years) & $15.8 \pm 0.73$ & \\
Hb Levels $(\mathrm{g} / \mathrm{dl})$ & $13.32 \pm 1.69$ & \\
Anemic $(<12 \mathrm{~g} / \mathrm{dL})$ & & $20(17.1)$
\end{tabular}

Non-anemic $(>12 \mathrm{~g} / \mathrm{dL})$

$97(82.9)$

Fruit consumption (g/ day)

Inadequate $(<150 \mathrm{~g} /$ person/day $)$

Adequate ( $>150 \mathrm{~g} /$ person/ day)

Vegetable consumption (g/day)

Inadequate $(<250 \mathrm{~g} /$ person/day)

Adequate ( $>250 \mathrm{~g} /$ person/ day)

Fruits + vegetables (g/ day)

Inadequate $(<400 \mathrm{~g} /$ person/day $)$

Adequate ( $>400 \mathrm{~g} /$ person/ day)

Physical activity (METs)

Low (<600 METs)

Medium (600-2999 METs)

High (>3000 METs)

Menstrual length (days)

Abnormal (>7 days/cycle)

Normal $(\leq 7$ days/cycle $)$

BMI for Age (z-score)

Thin (-3 SD to <-2 SD)

Normal (-2 SD to +1 SD)

Overweight $(+1 \mathrm{SD}$ to $+2 \mathrm{SD})$

Obese $(>+2$ SD)

Parent income (million rupiah)

$<$ MRW (million IDR)

$\geq$ MRW (million IDR)

$111.56 \pm 27.30$

101(86.3)

16(13.7)

$252.77 \pm 110.12$

$56(47.9)$

$61(52.1)$

$364.32 \pm 119.69$

$79(67.5)$

$38(32.5)$

$1558.1 \pm 1350$

$32(27.4)$

$67(57.3)$

$18(15.4)$

$6.33 \pm 1.12$

9(7.7)

108(92.3)

$-0.23 \pm 1.23$

14(12)

94(80.3)

2(1.7)

7(6)

$1.865 \pm 1.1154$

$77(56.4)$ $51(43.6)$

TABLE II. THE AVERAGE CONSUMPTION OF FRUITS AND VEGETABLES IN ANEMIC AND NON-ANEMIC YOUNG WOMEN

\begin{tabular}{ccccc}
\hline Hb levels & $\mathbf{N}$ & $\begin{array}{c}\text { Fruits } \\
(\mathbf{g} / \mathbf{d a y})\end{array}$ & $\begin{array}{c}\text { Daily Consumption } \\
\text { Vegetables } \\
(\mathbf{g} / \mathbf{d a y})\end{array}$ & $\begin{array}{c}\text { Fruits }+ \\
\text { Vegetables } \\
(\mathbf{g} / \mathbf{d a y})\end{array}$ \\
\hline $\begin{array}{c}\text { Anemia } \\
(<12 \mathrm{~g} / \mathrm{dL})\end{array}$ & 20 & $100.77 \pm 22.93$ & $159.79 \pm 79.12$ & $260.57 \pm 89.81$ \\
$\begin{array}{c}\text { Non-anemia } \\
(\geq 12 \mathrm{~g} / \mathrm{dL})\end{array}$ & 97 & $113.78 \pm 27.69$ & $271.94 \pm 106.02$ & $385.71 \pm 114.04$ \\
\hline
\end{tabular}

Table 2 showed that daily consumption of fruits, vegetables or combination in anemic young women was lower than daily consumption of fruits, vegetables or combination in non-anemic young women. However, young women with anemia daily consumed fruits slightly different from those with non- anemia (100.77 vs. $113.78 \mathrm{~g} /$ day).

TABLE III. THE CORREATIONS OF FRUIT AND VEGETABLE CONSUMPTIONS AND CONFOUNDING FACTORS WITH HB LEVELS IN YOUNG WOMEN

\begin{tabular}{lll}
\hline \multicolumn{1}{c}{ Variable } & \multicolumn{1}{c}{ r } & \multicolumn{1}{c}{$\mathbf{p}$} \\
\hline Independent variable & \multicolumn{2}{c}{} \\
Fruit consumption & 0.188 & 0.042 \\
Vegetable consumption & 0.399 & $<0.001$ \\
Confounding factors & & \\
Physical activity & 0.038 & 0.687 \\
Menstrual length & -0.23 & 0.013 \\
BMI for Age & 0.156 & 0.094 \\
Parent income & 0.12 & 0.199 \\
\hline
\end{tabular}

In order to assess independent correlations of fruit and vegetable consumptions and confounding factors with $\mathrm{Hb}$ levels, the Spearman test was carried out. Table 3 showed that fruit and vegetable consumptions and menstrual length had significant correlations with $\mathrm{Hb}$ levels. Daily fruit consumption $(r=0.188 ; p=0.042)$ and daily vegetable consumption $(r=0.399 ; p<0.001)$ positively correlated with $\mathrm{Hb}$ levels while a negative correlation was for menstrual length $(r=-0.23 ; \mathrm{p}=0.013)$.

The next statistical analysis used the multiple linier regression test for evaluating the correlation of all factors 
together with $\mathrm{Hb}$ levels. Only daily consumption of vegetables positively correlated with $\mathrm{Hb}$ level after adjustment with physical activity, menstrual length, BMI for age, and parent income (Table 4). Meanwhile, changes of $\mathrm{Hb}$ levels in young women were also influenced by the length of menstruation.

TABLE IV. THE MULTIVARIATE ANALYSIS OF FRUIT AND VEGETABLE CONSUMPTIONS AND CONFOUNDING FACTORS WITH Hв LEVELS IN YOUNG WOMEN

\begin{tabular}{ccccc}
\hline Variables & $\mathbf{b}^{*}$ & $\mathbf{t}$ & sig & $\boldsymbol{\beta}^{* *}$ \\
\hline Constant & 12.738 & 12.338 & 0.000 & \\
Fruit consumption & 0.002 & 0.333 & 0.740 & 0.029 \\
Vegetable & 0.006 & 4.785 & $<0.001$ & 0.404 \\
consumption & & & & \\
Physical activity & 0.000 & 1.243 & 0.216 & 0.103 \\
Menstrual length & -0.249 & -2.039 & 0.044 & -0.172 \\
BMI / Age & 0.172 & 1.567 & 0.12 & 0.131 \\
Parent income & 0.171 & 1.413 & 0.161 & 0.118 \\
R square $=0.264$ & $\mathrm{~F}=6.587$ & $p(\operatorname{sig})=0.000$ \\
\multicolumn{5}{c}{ n observations = 117} \\
$\mathrm{~b}^{*}=$ Unstandardized coefficients \\
$\beta^{* *}=$ standardized coefficients \\
\hline
\end{tabular}

\section{DISCUSSION}

Adequate intake of fruits and vegetables is one of the healthy diet components to keep normal human body functions, based on Balanced Nutrition Message 2014, at least $150 \mathrm{~g} /$ person/day and $250 \mathrm{~g} /$ person/day respectively [10]. However, most young women in this study only consumed approximately $111.56 \mathrm{~g} /$ day fruits. In addition, all young women with anemia had low consumption of fruits and vegetables, which could be influenced by several factors such as parent income [15]. A previous study has showed that higher parent income correlates to higher amount of fruit consumption in young women [16].

It is not surprised that fruit consumption did not correlate to Hb levels ( $\mathrm{b}=0.002 ; 95 \% \mathrm{CI}=-0.008$ to $0.012 ; \mathrm{p}>0.05$ ) in young women since $86.3 \%$ among them had a low fruit consumption. For young women with anemia, daily consumption of fresh fruits perhaps affect the iron absorption [8]. From our finding, vegetable consumption slightly increases $\mathrm{Hb}$ levels in young women as well $(b=0.006 ; 95 \%$ $\mathrm{CI}=0.003-0.008 ; \mathrm{p}<0.05)$ because the proportion of vegetable consumption between young women with anemia and young women without anemia is slightly difference (47.9 vs. $52.1 \%)$. Secondly, vegetables are rich ferric iron that requires the presence of vitamin $\mathrm{C}$ to convert into ferro iron [17-19]. Therefore, it will need longer time to increase $\mathrm{Hb}$ levels than daily consumption of meat and dairy products. Vegetables also contain carotenoids as a precursor of vitamin A formation in the human body that help the iron absorption in the small intestine through mobilization of iron from ferritin into all body tissues [20]. Another study has reported that vitamin $A$ activates the expression of ferroportin 1 in cells $\mathrm{Caco}-2$, which causes iron to pass through the intestinal cell membrane and increasing iron absorption [21]. A similar study reveals that consumption of spinach for 7 days increases the mean $\mathrm{Hb}$ levels from 12.80 $\mathrm{g} / \mathrm{dL}$ to $13.18 \mathrm{~g} / \mathrm{dL}$ [22].

Menstrual duration in this study was found to have a negative correlation with $\mathrm{Hb}$ levels $(\mathrm{b}=-0.249 ; 95 \% \mathrm{CI}=$ 0.49 to $-0.007 ; \mathrm{p}<0.05)$. This finding is in line with the theory that regular menstruation can cause iron loss [23]. Our study supports a previous research study that adolescent girls with menstrual periods $\geq 5$ days have 2.4 higher risk of developing anemia compared to those with the menstrual periods $<5$ days [15]. Altogether, consumption of fruits and vegetables and confounding factors significantly influence $\mathrm{Hb}$ levels by $26.4 \%$ and many other factors contribute to $\mathrm{Hb}$ levels such as daily intake of protein and heme-rich foods.

\section{CONCLUSION}

Daily consumption of vegetables positively correlates with $\mathrm{Hb}$ level in young women at Karanganyar Regency but that of fruits does not. This finding suggests that regular consumption of vegetables plays an important role for preventing iron deficiency anemia in consideration of menstrual length of every young woman. Moreover, we aware that our study just used limited number of research participants so that we could not generalize our result to Indonesian population. In future, we will recruit a large number of research participants to complete our study and involve other factors that contribute to $\mathrm{Hb}$ production.

\section{REFERENCES}

[1] WHO, Prevalence of Anaemia in Women of Reproductive Age (\%). Geneva, 2017.

[2] The Ministry of Health of Republic of Indonesia, National Riskesdas Report 2018, Jakarta: Health Research and Development Agency Ministry of Health Republic of Indonesia, 2018.

[3] C. Camaschella, "Iron-Deficiency Anemia," N. Engl. J. Med., vol. 372, no. 19 , pp. 1832-1843, 2015.

[4] J. D. Haas and T. Brownlie, "Iron deficiency and reduced work capacity: A critical review of the research to determine a causal relationship," J. Nutr., vol. 131, no. 2, pp. 676S-690S, 2001.

[5] Hermina and P. S, "Fruits and Vegetables Consumption of Indonesian Polulation in the Context of Balanced Nutrition: A Further Analysis of Individual Food Consumption Survey (SKMI) 2014,” Bul. Penelit. Kesehat., vol. 44, no. 3, pp. 205-218, 2016.

[6] D. J. R. Lane, D. Bae, A. M. Merlot, S. Sahni, and D. R. Richardson, "Update on Function and Regulation," Nutrients, vol. 7, pp. 22742296, 2015.

[7] H. Masthalina, Y. Laraeni, and PY Dahlia, "Consumption Pattern (Inhibitor Factors and Fe Enhancers) for Adolescent Girls Anemia Status," J. Kesehat. Masy., vol. 11, no. 1, pp. 80-86, 2015.

[8] B. Ghose and S. Yaya, "Fruit and Vegetable Consumption and Anemia among Adult non-Pregnant Women: Ghana Demographic and Health Survey," PeerJ, vol. 6, no. e4414, pp. 1-16, 2018.

[9] Y. P. Fitri, D. Briawan, I. Tanziha, and S. Madanijah, "Adequacy and Bioavailability of Iron Intake among Pregnant Women in Tangerang," Media Kesehat. Masy. Indonesia., vol. 12, no. 3, pp. 185-191, 2016.

[10] The Ministry of Health of the Republic of Indonesia, Regulation of the Ministry of Health of the Republic of Indonesia Number 41 of 2014 about Balanced Nutrition Guidelines. Jakarta: Ministry of Health of the Republic of Indonesia, 2014.

[11] The Ministry of Health of the Republic of Indonesia, Clinical Data Interpretation Guidelines. Jakarta: Ministry of Health of the Republic of Indonesia, 2011.

[12] C. L. Craig et al., "International Physical Activity Questionnaire : 12 Country Reliability and Validity," Med. Sci. Sport. Exerc., vol. 35, no. 8, pp. 1381-1395, 2003.

[13] Central Java Governor of Indonesia, Decision of The Governor of Central Jawa Number 560/58 of 2019 about Minimum Wages for 35 (Thirty Five) Districts/Cities in The Province of Central Java of 2020. Central Java: Central Java Governor, 2019.

[14] The Ministry of Health of the Republic of Indonesia, Regulation of the Ministry of Health of the Republic of Indonesia Number 2 of 2020 about Childrens's Anthropometry standards. Jakarta: The Ministry of Health of the Republic of Indonesia, 2020. 
[15] G. Mengistu, M. Azage, and H. Gutema, "Iron Deficiency Anemia among In-School Adolescent Girls in Rural Area of Bahir Dar City Administration, North West Ethiopia," Hindawi, pp. 1-8, 2019.

[16] N. Suryani, R. Anwar, and H. K. Wardani, "Correlation of Economic Status With Fruit, Vegetable Consumption and Nutrition Knowledge toward Nutritional Status of Students in Junior High School of Urban and Sub-Urban at Banjarbaru in the Year 2014," Indones. J. Heal., vol. 5, no. 3, pp. 6-15, 2015.

[17] S. J. Padayatty and M. Levine, "Vitamin C physiology: the known and the unknown and Goldilocks," Oral Dis., vol. 22, no. 6, pp. $463-$ 493, 2016.

[18] S. Waldvogel-abramowski et al., "Physiology of Iron Metabolism," Transfus. Med. Hemotherapy, vol. 41, pp. 213-221, 2014.

[19] D. Siallagan, P. D. Swamilaksita, and D. Angkasa, "The effect of iron, vitamin $\mathrm{A}$, vitamin $\mathrm{B} 12$, and vitamin $\mathrm{C}$ intake on hemoglobin levels in vegetarian adolescents," J. Gizi Klin. Indones., vol. 13, no. 2, pp. 67-74, 2016.
[20] N. Abbaspour, R. Hurrell, and R. Kelishadi, "Review on Iron and Its Importance for Human Health," J. Res. Med. Sci., vol. 19, no. 2, pp. 164-174, 2014.

[21] M. Citelli, L. L. Bittencourt, S. V. da Silva, A. P. T. Pierucci, and C. Pedrosa, "Vitamin A Modulates the Expression of Genes Involved in Iron Bioavailability Vitamin A Modulates the Expression of Genes Involved in Iron Bioavailability," Biol. Trace Elem. Res., vol. 149, pp. 64-70, 2012.

[22] R. I. Suhada, A. Fitriani, and F. L. Widiany, "Effectiveness of Spinach to Levels of Hemoglobin of Adolescent in Junior High School 3 Kalasan, Sleman, Yogyakarta," J. Food and Nutrition, vol. 9, no. 1, pp. 16-26, 2019.

[23] V. Mishra, R. Verneker, K. Gandhi, S. Choudhary, and S. Lamba, "Iron Deficiency Anemia with Menorrhagia: Ferric Carboxymaltose a Safer Alternative to Blood Transfusion," J. Midlife. Health, vol. 9, pp. 185-190, 2018. 